\title{
Relationship Between Vitamin D and Cardio-Metabolic Biomarkers Among Saudi Postmenopausal Women
}

\author{
Eman M. Alissa ${ }^{1, *}$, Wafa A. Alnahdi ${ }^{1}$, Nabeel Alama $^{1}$ and Gordon A. Ferns ${ }^{2}$ \\ ${ }^{1}$ Faculty of Medicine, King AbdulAziz University, P.O. Box 12713, Jeddah 21483, Saudi Arabia \\ ${ }^{2}$ Medical Education and Metabolic Medicine, Brighton and Sussex Medical School, University of Brighton, \\ BN1 9PH, UK
}

\begin{abstract}
Vitamin D deficiency is prevalent worldwide, and in Saudi Arabia in particular. There is growing evidence that hypovitaminosis $\mathrm{D}$ is involved in the pathogenesis of cardiovascular diseases. We determined concentrations of serum 25 hydroxy $25(\mathrm{OH})$ vitamin $\mathrm{D}$ in relation to several metabolic biomarkers including total cholesterol (TC), low density lipoprotein-cholesterol (LDL-C), high density lipoprotein-cholesterol, triglycerides (TG), atherogenic index (Al), glucose, C-reactive protein (CRP), adiposity, and blood pressure in a cross-sectional analysis in 300 Saudi postmenopausal women. Participants completed a detailed questionnaire and fasting blood samples were collected. Vitamin $\mathrm{D}$ deficiency was common, affecting $89 \%$ of individuals. Higher serum $25(\mathrm{OH})$ vitamin D levels were consistently found among subjects with no prevalent cardiovascular risk factors ( $p>0.05$ ) except for those subjects with serum CRP level $\geq 3 \mathrm{mg} / \mathrm{dl}$, $\mathrm{HDL}-\mathrm{C}<1.04 \mathrm{mmol} / \mathrm{L}, \mathrm{Al} \geq 5$, exercising $\geq 3$ times/week, and those with 4 or more pregnancies. Hypovitaminosis $\mathrm{D}$ was inversely correlated with DBP $(r=-0.118, p=0.042)$, TC $(r=-0.165, p=0.004)$, TG $(r=-0.119, p=0.040)$, LDL-C $(r=-0.138$, $p=0.017)$, Al $(r=-0.125, p=0.031)$, and veiling type $(r=-0.127, p=0.028)$. No significant impact of hypovitaminosis $D$ on CRP, levels of which were similar among vitamin D sufficient and deficient subjects. However, hypovitaminosis D was significantly related to dyslipidemia and diastolic blood pressure in a group of Saudi postmenopausal women.
\end{abstract}

Keywords: Hypovitaminosis D, cardiovascular risk factors, Saudi postmenopausal women.

\section{INTRODUCTION}

The Arabian Gulf region has experienced dramatic increase in the prevalence rates of vitamin $D$ deficiency [1-3]. The negative impact of urbanization has resulted in significant demographic and lifestyle changes. Clearly low levels of vitamin $D$ are related to compromised bone mineral density, to falls and fractures [4]. In addition, hypovitaminosis D can adversely affect tissues that are not involved in calcium homeostasis and bone metabolism [5]. Although a growing body of evidence suggested a role for hypovitaminosis $D$ in the pathogenesis of cardiovascular diseases (CVD), the importance of adequate vitamin $D$ intake has often been neglected [6]. Epidemiological evidence showed an association of low 25-hydroxyvitamin $D(25[\mathrm{OH}] \quad$ D) levels with important cardiovascular risk factors [7,8]. Vitamin D level affects vascular smooth muscle cell proliferation, inflammation, vascular calcification, the reninangiotensin system, and blood pressure, all of which affect risk of CVD and myocardial infarction [9]. Of many inflammatory markers, C-reactive protein (CRP) is the one that is most consistently related to cardiovascular risk [10]. Serum 25-hydroxyvitamin D concentrations are exceedingly determined by environmental factors, including dietary intake and

*Address correspondence to this author at the Faculty of Medicine, King Abdul Aziz University, P.O. Box 12713, Jeddah 21483, Kingdom of Saudi Arabia; Tel: (966) 26400000 Ext. 23432; Fax: (966) 2 6643499;

E-mail: em_alissa@yahoo.com exposure to sunlight [11]. Estrogen deficiency in the postmenopausal period is a risk factor for both CVD and osteoporosis as well as increasing centrally deposited fat $[12,13]$. It has been estimated that about $60 \%$ of the older populations worldwide do not have satisfactory vitamin $D$ status and the situation is similar in younger subjects for unclear reasons [14]. The serum concentration of $25(\mathrm{OH}) \mathrm{D}$ is the best marker of total body vitamin $\mathrm{D}$ status and clinical vitamin $\mathrm{D}$ deficiency is defined as a serum $25(\mathrm{OH}) \mathrm{D}<50 \mathrm{nmol} / \mathrm{L}$ [4]. Grading of serum vitamin D deficiency into sufficient, insufficient, and deficient categories is very important in determining cardiovascular risk [15].

\section{OBJECTIVES}

To investigate whether low serum $25(\mathrm{OH}) \mathrm{D}$ concentrations may contribute to cardio-metabolic disease through effects on metabolic biomarkers and adiposity, concentrations of serum $25(\mathrm{OH}) \mathrm{D}$ was determined in relation to metabolic biomarkers including total cholesterol, Low-density lipoprotein cholesterol (LDL-C), high density lipoproteincholesterol (HDL-C), triglycerides, atherogenic index, glucose, CRP, measures of adiposity, and blood pressure values.

\section{METHODS}

A cross-sectional analysis was conducted in 300 Saudi postmenopausal women, aged 48 to 88 years, 
who were unselectively recruited from the Department of Internal Medicine at King Abdulaziz University Hospital. Postmenopausal status was defined as no natural menses for $\geq 1$ year and serum folliclestimulating hormone level $>40 \mathrm{IU} / \mathrm{L}$ [16]. All study participants gave their informed consent, and the ethics committee at the KAUH approved the study. The primary exclusion criteria were the presence of liver or renal diseases, inflammatory diseases, vascular disease, osteoporosis, endocrine diseases, taking any drug treatment that may have possible effects on bone metabolism, statins, aspirin, antioxidants, vitamin D or calcium supplementations.

Participants completed a detailed questionnaire regarding age, socio-demographic, medical and family histories, medication and supplement use, lifestyle habits including smoking status, and recreational physical activity.

Height was measured in $\mathrm{cm}$ using a stadiometer, and weight was measured in $\mathrm{kg}$ with a balance scale. Body mass index (BMI) was calculated (in $\mathrm{kg} / \mathrm{m}^{2}$ ). overweight (BMI, $25-29.9 \mathrm{~kg} / \mathrm{m}^{2}$ ) and obesity (BMI $\geq 30$ $\mathrm{kg} / \mathrm{m}^{2}$ ) were determined by the clinical guidelines on the identification, evaluation and treatment of overweight and obesity in adults [17]. Waist and hip circumferences were measured in centimeters using a tape measure. Waist-to-hip ratio (WHR) was calculated as the ratio of waist and hip circumferences. Measurement of the waist circumference (WC) was considered as a surrogate for visceral adipose tissue and was considered high when waist $>88 \mathrm{~cm}$ [18]. WHR was used to assess body fat distribution considering and value $\geq 0.80$ was considered high [19]

Arterial blood pressure was measured using the right arm (average of 3 measurements with the patient seated and rested for 5 minutes). To avoid subjective error, all measurements were taken by the same trained staff. Hypertension was defined as a systolic blood pressure (SBP) $\geq 140 \mathrm{mmHg}$, and/or diastolic blood pressure (DBP) $\geq 90 \mathrm{mmHg}$, or current use of antihypertensive medication [20].

Smoking habit was categorized as non-smoker, former smoker, and current smoker. Physical activity was self-graded by the participant according to the number of episodes of physical exercise performed per week and were categorized as active ( $\geq 3$ times/week) or inactive ( $<3$ times/week) [21].

Blood samples were obtained after fasting for at least $12 \mathrm{~h}$ for subsequent biochemical analysis. All the samples were stored at $-80^{\circ} \mathrm{C}$ until analytical measurements were performed. Fasting blood glucose level was estimated immediately after blood was drawn. Glucose, TC, HDL-C, and TG were determined in duplicate using the enzymatic colorimetric assays. LDL-C was calculated using the Friedewald formula in samples where the triglycerides were $<4 \mathrm{mmol} / \mathrm{L}$. All analytes were measured using kits and reagents supplied by Ortho-Clinical Diagnostics, USA, using Vitros 250 Chemistry System Autoanalyzer (OrthoClinical Diagnostics, Johnson \& Johnson Co, USA). Dyslipidaemia was defined as serum levels of total cholesterol $(\mathrm{TC}) \geq 5.2 \mathrm{mmol} / \mathrm{L}(\geq 200 \mathrm{mg} / \mathrm{dl})$, LDL-C $\geq 3.36 \mathrm{mmol} / \mathrm{L}(\geq 130 \mathrm{mg} / \mathrm{dl}), \mathrm{HDL}-\mathrm{C}<1.04 \mathrm{mmol} / \mathrm{L}(<40$ $\mathrm{mg} / \mathrm{dl})$, triglycerides $(\mathrm{TG}) \geq 1.7 \mathrm{mmol} / \mathrm{L}(\geq 150 \mathrm{mg} / \mathrm{dl})$ and/or if hypolipidemic treatment was administered [22]. Diabetes was defined as a known history of diabetes mellitus (fasting blood glucose (FBG) $\geq 7$ $\mathrm{mmol} / \mathrm{L}(\geq 126 \mathrm{mg} / \mathrm{dl})$ ) or treatment with insulin or oral hypoglycemic agents [23].

Serum CRP was measured by an enzymatic immunoassay High Sensitivity Kit (Dade Bering USA). As a marker of inflammation, prediction of coronary risk was defined by CRP levels of $<1,1$ to 2.9 , and $\geq 3$ $\mathrm{mg} / \mathrm{dl}$ that represent low, intermediate, and high-risk groups [10]. Serum 25(OH)D was measured with the DiaSorin Liaison 25(OH)D chemiluminescent immunoassay system at Diasorin headquarters (DiaSorin Inc, Stillwater, MN, USA). Serum vitamin D level was further categorized as $(<50 \mathrm{nmol} / \mathrm{L}, 50-$ $74.9 \mathrm{nmol} / \mathrm{L}$, and $\geq 75 \mathrm{nmol} / \mathrm{L}$ ) [15].

Data are expressed as mean \pm SD. Data normalization were performed by log-transformation before any statistical analysis. Differences between the vitamin $D$ deficient and sufficient groups were estimated using unpaired Student $t$ tests for normally distributed variables (or Mann-Whitney $U$ to compare non-normal distributed variables). ANOVA test or Kruskal-Wallis test was applied for multiple comparisons. Bonferroni post hoc test was used whenever appropriate. Chi square test was used to compare categoric variables. The strength of association between different measured parameters was estimated by Pearson and Spearman correlation coefficient. Furthermore, multiple linear regression analysis was used to determine the associations between serum $25(\mathrm{OH}) \mathrm{D}$ (as a continuous variable) and independent predictors while controlling for potential covariates (e.g., age). The choice of covariates as potential confounding factors was based on prior studies and/or their biological plausibility. All 
Table 1: Mean 25-Hydroxyvitamin D Across Lifestyle and Clinical Characteristics in 300 Postmenopausal Women

\begin{tabular}{|c|c|c|c|}
\hline Characteristics & $\%$ Population & Serum 25(OH)D (nmol/L) & $p$ \\
\hline $\begin{array}{l}\text { Physical activity } \\
<1 \text { time } \\
1-2 \text { times } \\
>3 \text { times }\end{array}$ & $\begin{array}{c}119(40) \\
55(18) \\
126(42)\end{array}$ & $\begin{array}{l}33.9 \pm 2.3 \\
24.9 \pm 1.9 \\
31.2 \pm 1.4\end{array}$ & $<0.05$ \\
\hline $\begin{array}{l}\text { Smoking status } \\
\text { Non-smoker } \\
\text { Former smoker } \\
\text { Current smoker }\end{array}$ & $\begin{array}{c}282(94) \\
8(3) \\
10(3)\end{array}$ & $\begin{array}{l}31.3 \pm 1.2 \\
26.8 \pm 5.6 \\
29.8 \pm 5.0\end{array}$ & NS \\
\hline $\begin{array}{l}\text { Exposure to sunlight } \\
<1 \text { time } \\
1-2 \text { times } \\
>3 \text { times }\end{array}$ & $\begin{array}{c}219(73) \\
68(23) \\
13(4)\end{array}$ & $\begin{array}{l}31.1 \pm 1.4 \\
30.4 \pm 2.2 \\
35.3 \pm 5.5\end{array}$ & NS \\
\hline $\begin{array}{l}\frac{\text { Parity }}{<4 \text { kids }} \\
\geq 4 \text { kids }\end{array}$ & $\begin{array}{c}42(14) \\
258(86)\end{array}$ & $\begin{array}{l}29.6 \pm 1.8 \\
31.4 \pm 1.3\end{array}$ & NS \\
\hline $\begin{array}{l}\text { BMl classes } \\
\text { Normal }\left(<25 \mathrm{Kg} / \mathrm{m}^{2}\right) \\
\text { Overweight }\left(25 \mathrm{Kg} / \mathrm{m}^{2}-29.99 \mathrm{Kg} / \mathrm{m}^{2}\right) \\
\text { Obese }\left(\geq 30 \mathrm{Kg} / \mathrm{m}^{2}\right)\end{array}$ & $\begin{array}{c}19(6) \\
96(32) \\
185(62)\end{array}$ & $\begin{array}{l}33.2 \pm 7.4 \\
31.9 \pm 2.1 \\
30.5 \pm 1.4\end{array}$ & NS \\
\hline $\begin{array}{l}\frac{\text { WC classes }}{\text { Normal }<88 \mathrm{~cm}} \\
\text { Obese }>88 \mathrm{~cm}\end{array}$ & $\begin{array}{c}45(15) \\
255(85)\end{array}$ & $\begin{array}{l}31.8 \pm 3.6 \\
31.0 \pm 1.2\end{array}$ & NS \\
\hline $\begin{array}{l}\mathrm{HDL}-\mathrm{C} \geq 1.04 \mathrm{mmol} / \mathrm{L} \\
\mathrm{HDL}-\mathrm{C}<1.04 \mathrm{mmol} / \mathrm{L}\end{array}$ & $\begin{array}{c}234(78) \\
66(22)\end{array}$ & $\begin{array}{l}31.1 \pm 1.4 \\
31.3 \pm 2.2\end{array}$ & NS \\
\hline $\begin{array}{l}\text { LDL-C }<3.36 \mathrm{mmol} / \mathrm{L} \\
\mathrm{LDL}-\mathrm{C} \geq 3.36 \mathrm{mmol} / \mathrm{L}\end{array}$ & $\begin{array}{c}247(82) \\
53(18)\end{array}$ & $\begin{array}{l}31.4 \pm 1.3 \\
29.9 \pm 2.9\end{array}$ & NS \\
\hline $\begin{array}{l}\text { TC/HDL-C ratio }<5.0 \\
\text { TC/HDL-C ratio } \geq 5.0\end{array}$ & $\begin{array}{c}254(85) \\
46(15)\end{array}$ & $\begin{array}{l}31.1 \pm 1.3 \\
31.6 \pm 2.7\end{array}$ & NS \\
\hline $\begin{array}{l}\mathrm{FBG}<7 \mathrm{mmol} / \mathrm{L} \\
\mathrm{FBG} \geq 7 \mathrm{mmol} / \mathrm{L}\end{array}$ & $\begin{array}{l}194(65) \\
106(35)\end{array}$ & $\begin{array}{l}31.2 \pm 1.4 \\
30.9 \pm 2.1\end{array}$ & NS \\
\hline $\begin{array}{l}S B P<140 \mathrm{mmHg} \\
S B P \geq 140 \mathrm{mmHg}\end{array}$ & $\begin{array}{l}166(55) \\
134(45)\end{array}$ & $\begin{array}{l}31.9 \pm 1.7 \\
30.1 \pm 1.6\end{array}$ & NS \\
\hline $\begin{array}{l}\mathrm{DBP}<90 \mathrm{mmHg} \\
\mathrm{DBP} \geq 90 \mathrm{mmHg}\end{array}$ & $\begin{array}{c}239(80) \\
61(20)\end{array}$ & $\begin{array}{l}32.1 \pm 1.4 \\
27.3 \pm 1.6\end{array}$ & NS \\
\hline $\begin{array}{l}\text { CRP level } \\
<1 \mathrm{mg} / \mathrm{dl} \\
1-2.9 \mathrm{mg} / \mathrm{dl} \\
\geq 0.30 \mathrm{mg} / \mathrm{dl}\end{array}$ & $\begin{array}{c}57(19) \\
94(31) \\
149(50)\end{array}$ & $\begin{array}{l}31.5 \pm 2.9 \\
29.9 \pm 1.8 \\
31.7 \pm 1.7\end{array}$ & NS \\
\hline
\end{tabular}

Data are given as the mean \pm SD or as percentages of subjects, as appropriate. Continuous variables are compared by unpaired t-test and ANOVA test. BMI: body mass index, CRP: C-reactive protein, DBP: diastolic blood pressure, FBG: fasting blood glucose, HDL-C: high density lipoprotein-cholesterol, LDL-C: low density lipoprotein-cholesterol, NS: not significant, BP: systolic blood pressure, TC: total cholesterol, TG: triglycerides, WC: waist circumference, WHR: waist-to-hip ratio. 
$P$ values were 2 -tailed, and $P<0.05$ was considered to indicate statistical significance. Statistical analyses were carried out using SPSS (version 20.0; SPSS, Chicago, IL, USA).

\section{RESULTS}

The mean serum $25(\mathrm{OH})$ vitamin $D$ level for the whole group was $31.13 \pm 1.16 \mathrm{nmol} / \mathrm{L}$. Hypovitaminsosis D was a common finding in this cohort affecting approximately $89 \%$ of individuals. The study participants were divided into the following categories of serum $25(\mathrm{OH})$ vitamin D concentrations $(<50,50$ 74.9 , and $\geq 75 \mathrm{nmol} / \mathrm{L}$ ) to show the extent of hypovitaminosis D in our study population. Only $7 \%$ and $4 \%$ of the postmenopausal women were considered vitamin D insufficient and sufficient respectively.
Study subjects were classified as high vs. low risk if they had any of the classical cardiovascular risk factors. Table 1 lists mean serum $25(\mathrm{OH})$ vitamin D levels by lifestyle and clinical characteristics. Higher serum $25(\mathrm{OH})$ vitamin $D$ levels were consistently found among subjects with no prevalent cardiovascular risk factors ( $p>0.05)$ except for subjects with serum CRP level $\geq 3 \mathrm{mg} / \mathrm{dl}$, HDL-C $<1.04 \mathrm{mmol} / \mathrm{L}$, TC/HDL-C ratio $\geq 5$, exercising $\geq 3$ times/week, and those with 4 or more pregnancies.

Despite the small number of subjects with vitamin $D$ sufficiency, the prevalence of traditional risk factors (as dichotomous variables) was higher in those with vitamin $\mathrm{D}$ deficiency, including hypertriglyceridemia ( $42 \%$ vs. $36 \%$ ), hypertension ( $46 \%$ vs. $39 \%$ ), obesity ( $96 \%$ vs. $91 \%)$, central obesity ( $86 \%$ vs. $79 \%)$, those with 4 or more pregnancies ( $85 \%$ vs. $94 \%$ ), and more

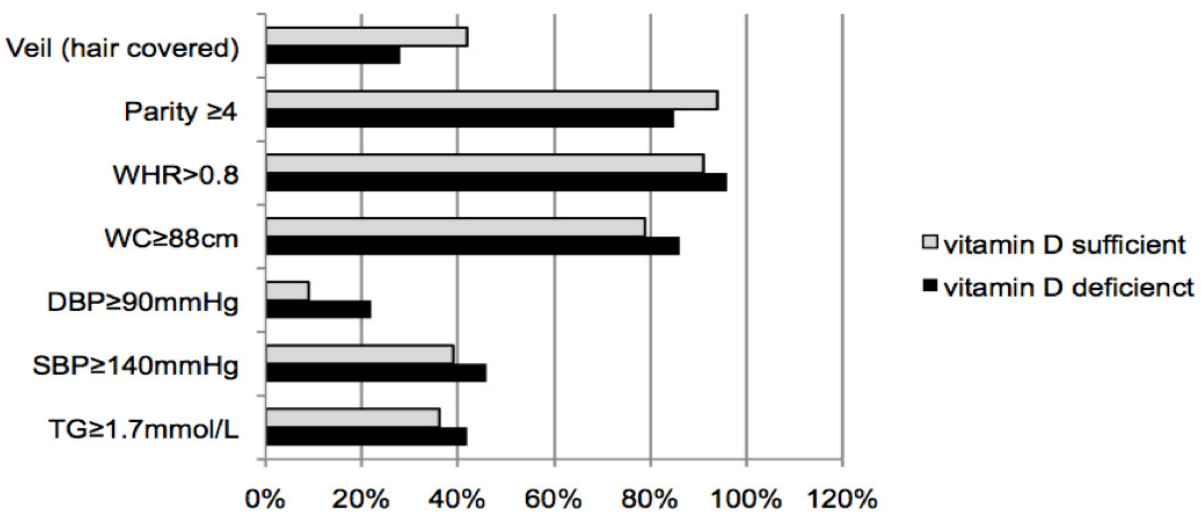

Figure 1: Prevalence of hypertension, hypertriglyceridemia, obesity, central obesity, multiparity, and veiling type among vitamin $D$ deficient and sufficient groups in the study population $(n=300)$.

Table 2: Clinical Characteristics of the Study Subjects in Relation to Vitamin D Status

\begin{tabular}{|c|c|c|c|c|}
\hline Characteristic & Total population $(n=300)$ & $\begin{array}{l}\text { Vitamin } D \text { deficient } \\
\text { group }(n=267)\end{array}$ & $\begin{array}{l}\text { Vitamin D sufficient } \\
\text { group }(n=33)\end{array}$ & $p$ \\
\hline BMI $\left(\mathrm{Kg} / \mathrm{m}^{2}\right)$ & $32.4 \pm 0.4$ & $32.5 \pm 0.4$ & $31.4 \pm 0.8$ & NS \\
\hline WC $(\mathrm{cm})$ & $100.0 \pm 0.8$ & $99.9 \pm 0.7$ & $100.2 \pm 3.4$ & NS \\
\hline WHR & $0.94 \pm 0.0$ & $0.95 \pm 0.03$ & $0.94 \pm 0.01$ & NS \\
\hline $\mathrm{SBP}(\mathrm{mmHg})$ & $135.2 \pm 1.3$ & $134.9 \pm 1.4$ & $136.9 \pm 3.3$ & NS \\
\hline $\mathrm{DBP}(\mathrm{mmHg})$ & $78.4 \pm 0.7$ & $78.8 \pm 0.8$ & $75.3 \pm 1.9$ & NS \\
\hline $\mathrm{TC}(\mathrm{mmol} / \mathrm{L})$ & $4.67 \pm 0.10$ & $4.67 \pm 0.07$ & $4.69 \pm 0.18$ & NS \\
\hline TG (mmol/L) & $1.83 \pm 0.06$ & $1.83 \pm 0.06$ & $1.82 \pm 0.2$ & NS \\
\hline HDL-C (mmol/L) & $1.83 \pm 0.06$ & $1.31 \pm 0.02$ & $1.35 \pm 0.07$ & NS \\
\hline LDL-C (mmol/L) & $2.50 \pm 0.06$ & $2.51 \pm 0.06$ & $2.49 \pm 0.14$ & NS \\
\hline TC/HDL-C ratio & $3.76 \pm 0.07$ & $3.76 \pm 0.08$ & $3.76 \pm 0.26$ & NS \\
\hline FBG (mmol/L) & $7.12 \pm 0.18$ & $7.06 \pm 0.19$ & $7.61 \pm 0.55$ & NS \\
\hline hs-CRP (mg/dl) & $4.90 \pm 0.4$ & $4.83 \pm 0.4$ & $5.99 \pm 1.2$ & NS \\
\hline
\end{tabular}

Data are given as the mean \pm SD or as percentages of subjects, as appropriate. Continuous variables are compared by unpaired t-test. BMI: body mass index, CRP C-reactive protein, DBP: diastolic blood pressure, FBG: fasting blood glucose, HDL-C: high density lipoprotein-cholesterol, LDL-C: low density lipoproteincholesterol, BP: systolic blood pressure, TC: total cholesterol, TG: triglycerides, WC: waist circumference, WHR: waist-to-hip ratio. 


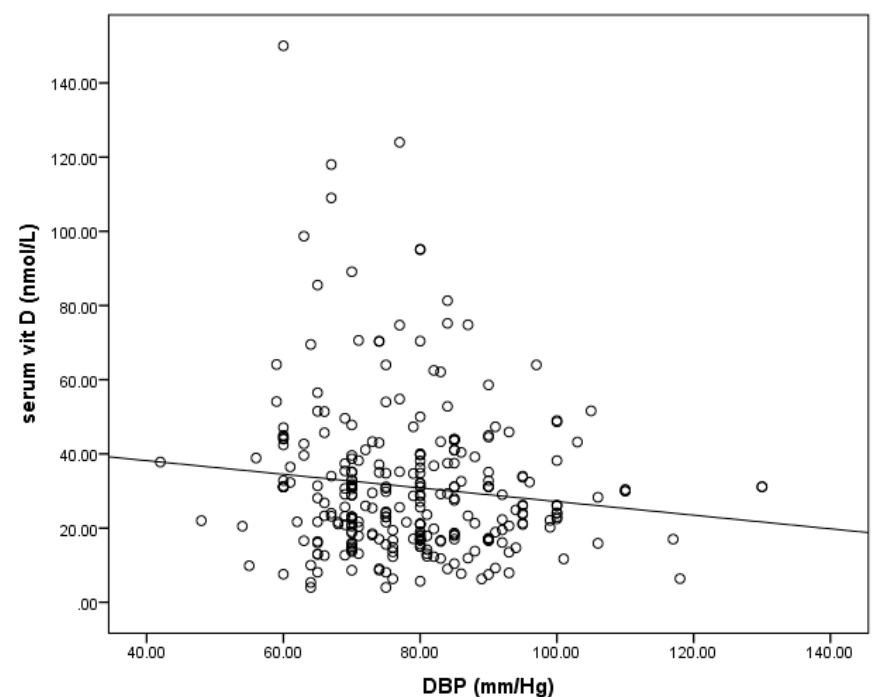

a

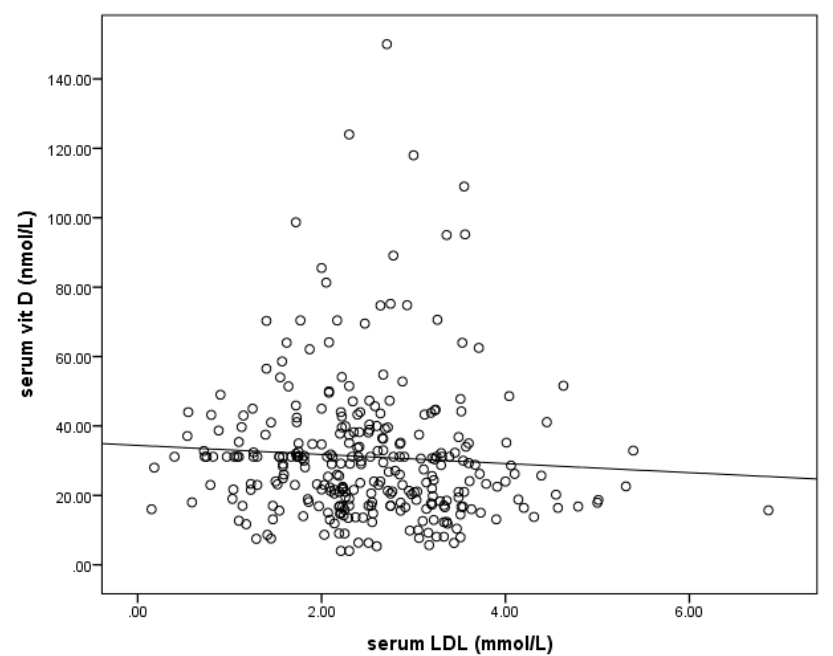

C

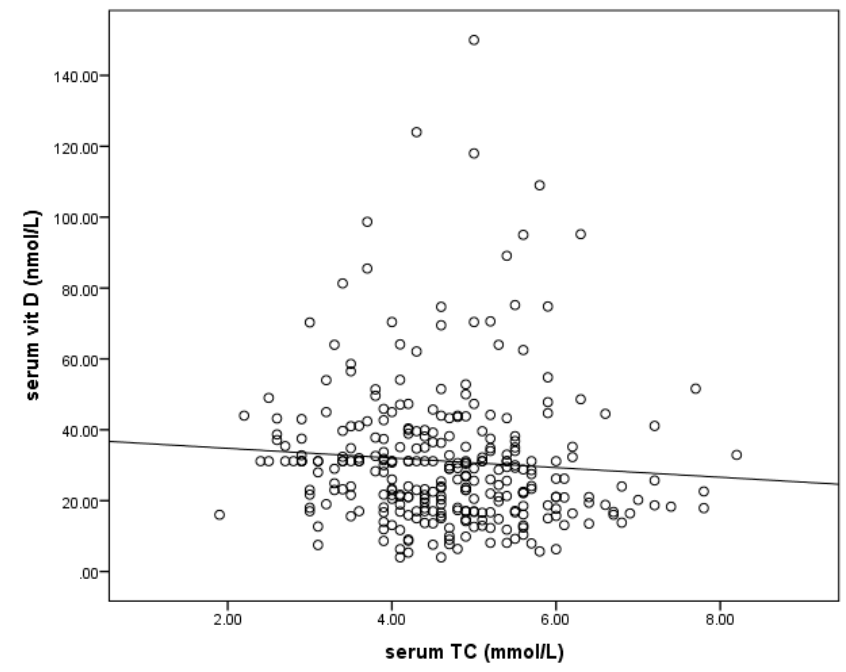

b

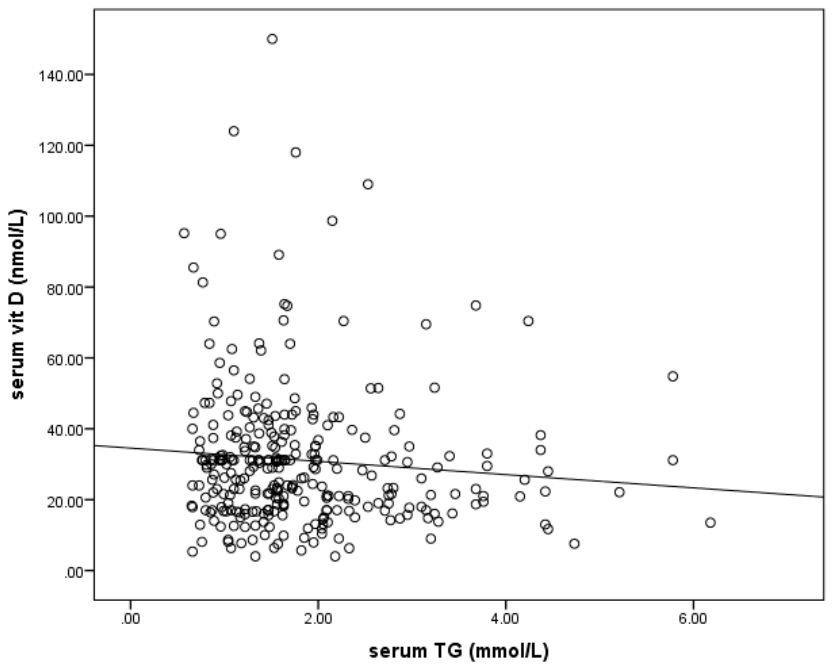

d

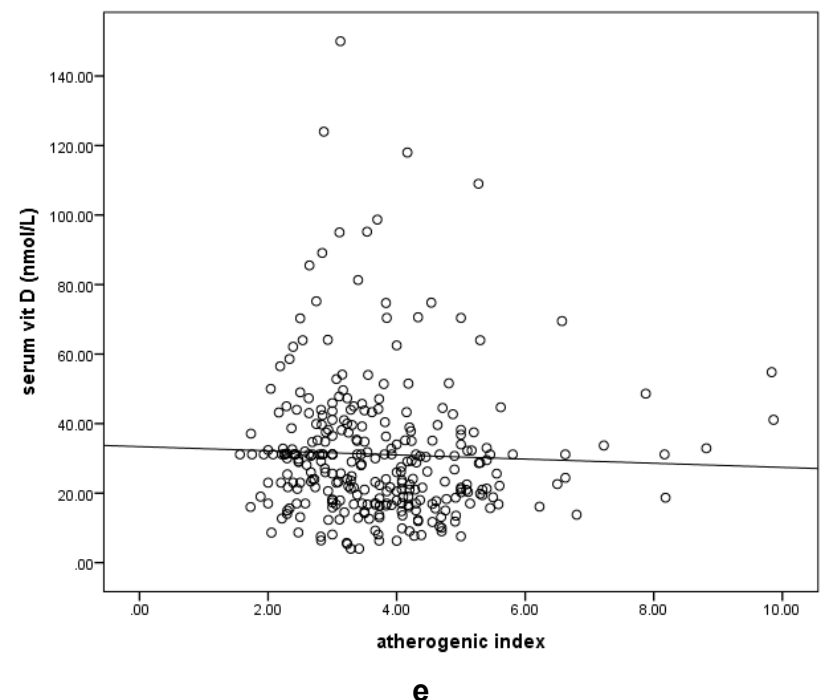

Figure 2: a. Scatter plot demonstrating correlation between serum 25-hydroxyvitamin $D$ and DBP in the whole population ( $r=-$ $0.118, \mathrm{P}<0.05)$. b. Scatter plot demonstrating correlation between serum 25-hydroxyvitamin D and TC in 300 postmenopausal women $(r=-0.165, P<0.01)$. c. Scatter plot demonstrating correlation between serum 25-hydroxyvitamin D and LDL-C in 300 postmenopausal women $r=-0.138, P<0.05)$. d. Scatter plot demonstrating correlation between serum 25-hydroxyvitamin $D$ and TG in 300 postmenopausal women $(r=-0.119, P<0.05)$. e. Scatter plot demonstrating correlation between serum 25hydroxyvitamin $\mathrm{D}$ and TC/HDL-C in 300 postmenopausal women $(r=-0.125, \mathrm{P}<0.05)$. 
subjects were covering their hair only as a veil $(42 \%$ vs. $28 \%$ ) than those in the vitamin $D$ sufficiency group (Figure 1). In addition, physical inactivity, inadequate sunlight exposure, multiparity, and adiposity, as determined by all anthropometric measures, were identified among $\approx 80 \%$ of the study population (Table 2).

Hypovitaminosis $D$ was found to be inversely related to DBP $(r=-0.118, p=0.042)$, TC $(r=-0.165$, $p=0.004)$, TG $(r=-0.119, p=0.040)$, LDL-C $(r=-0.138$, $p=0.017), T C / H D L-C$ ratio $(r=-0.125, p=0.031)$, and the veiling type as the groups progressed from hair covering to completely veiled $(r=-0.127, p=0.028)$ within the 300 postmenopausal women (Figure 2). However, no association was shown with the presence of obesity, diabetes, smoking status, sunlight exposure, and physical activity level. Multivariate analysis shows that only DBP was a significant independent predictor of vitamin $D$ status among our cohort of postmenopausal women $\left(R^{2}=14 \%, \beta=-0.184, p=0.042(95 \% \mathrm{Cl}:-0.360\right.$ to -0.007$))$.

There was no association between hypovitaminosis $D$ and serum levels of hs-CRP as a measure of inflammation. Furthermore, serum hs-CRP levels showed no difference among vitamin $D$ sufficient and deficient groups. However, more vitamin D deficient subjects were with intermediate coronary risk as defined by the serum CRP level $(1-2.9 \mathrm{mg} / \mathrm{dl})$ than those in the vitamin D sufficiency group (34\% vs. $15 \%$ ) whereas less vitamin $D$ deficient subjects were with high coronary risk as defined by the serum CRP level $(\geq 3 \mathrm{mg} / \mathrm{dl})$ than those in the vitamin $\mathrm{D}$ sufficiency group (48\% vs. $64 \%)$.

\section{DISCUSSION}

The high prevalence of hypovitaminosis $D$ of individuals living in the Arabian Gulf countries has been associated with conservative dress style, low intake of vitamin $D$, avoiding sunlight exposure with very high summer temperatures, a high number of pregnancies, obesity, and decreases in vitamin $\mathrm{D}$ production through skin with age but the situation is worse in younger subjects [2, 24]. In Saudi Arabia, women wear a full black cloak and may additionally shield parts of their face as well as hands and feet [25].

Adequate vitamin D status is subjected to skin pigmentation, lifestyle and environmental factors such as seasonal variation, and geographical latitude. In addition to limited physical activity, obesity and consumption of unbalanced meals are potential causes to also develop CVD early in life. A high prevalence of poor nutrition and high levels of markers of inflammation has been documented before, suggesting that combined lifestyle risk factors are implicated in the pathogenesis of CVD [26]. Although people with low serum vitamin $D$ levels are thought to be at increased cardiovascular risk [4], it is unclear whether $25(\mathrm{OH}) \mathrm{D}$ deficiency is related to prevalent CVD in Saudi Arabia [27].

In the present study, serum levels of $25(\mathrm{OH})$ vitamin $D$ were shown to be exceedingly below the recommended levels for a large portion of our cohort and that hypovitaminosis $\mathrm{D}$ was associated with an aggregate of dyslipidemias (TC, TG, LDL-C), diabetes and hypertension. These findings are consistent with the growing body of evidence suggesting that hypovitaminosis D may be implicated in the pathogenesis of hypertension, heart disease, and type 2 diabetes mellitus $[28,29]$. Similar results about the relationship of $25(\mathrm{OH})$ vitamin $D$ and CVD were reported in our study in spite of different patients populations characteristics and vitamin $D$ deficiency definition in those studies compared to ours. Increased adiposity has been consistently associated with hypovitaminosis D and adverse cardiovascular outcomes [30]. Our data reveal consistent finding demonstrated by high prevalence of obesity as indicated by anthropometrical indices (Table 2 ).

The mechanism explaining the association between adiposity and hypovitaminosis D needs to be fully determined. Several studies suggest a possible role for vitamin $D$ in insulin secretion, insulin resistance and systemic inflammation, all of which are involved in the pathogenesis of diabetes mellitus type 2 and metabolic syndrome [4]. Circulating levels of pro-inflammatory cytokines were found to be elevated in older subjects and have been linked to CVD and osteoporosis [31]. Based on evidence from in vitro studies, vitamin $D$ is suspected to affect insulin sensitivity and beta cell survival by modulating inflammatory cytokines. Nevertheless, there are few studies linking inflammatory markers with vitamin D status [32]. Prolonged vitamin D3 supplementation in vitamin Ddeficient subjects substantially lowered serum levels of hs-CRP [33] and had beneficial effects on the elastic properties of the common carotid artery in postmenopausal women [34]. Thereafter, our finding of no relationship between vitamin $D$ and hs-CRP is consistent with the fact that vitamin $D$ may not exert its 
immuno-modulatory effect via hs-CRP or interleukin 6 molecules as inflammatory markers. According to different cutoff values of serum hs-CRP level, more vitamin $\mathrm{D}$ deficient subjects were categorized in the intermediate coronary risk class $(34 \%$ vs. $15 \%)$ in contrast with more vitamin D sufficient subjects categorized in the high coronary risk class $(48 \%$ vs. $64 \%$ ). Thus hypovitaminosis $\mathrm{D}$ cannot be used to assess the early presence of inflammation potentially linked to cardiovascular risk.

Unlike our study results, inverse associations between vitamin $D$ level and/or vitamin $D$ intake on the incidence of type 2 diabetes or surrogate indices were consistently reported by many observational studies. However, these studies were performed on healthy subjects and did not examine the presence of these metabolic relationships among diabetic patients. Possibly much higher levels of vitamin $D$ at an early stage of diabetes are required to see if such a significant impact on metabolic control exists.

Findings of epidemiological studies linking low vitamin $D$ levels with CVD are being criticized for the fact that vitamin $D$ is a fat-soluble vitamin and such associations may simply attributed to larger distribution volume of the vitamin in obese subjects who are also more liable to diabetes, dyslipidemia, and hypertension by effect of their adiposity. Therefore, hypovitaminosis D levels may simply coexist with adiposity, physical inactivity and metabolic consequences of ageing, without being involved in the pathogenesis of cardiovascular outcomes. Nevertheless ethnicity plays an important role as previously found in observational studies that vitamin $D$ associations are ethnic specific probably due to differences in calcium homeostasis or different vitamin $\mathrm{D}$ receptor polymorphisms. Thus, our findings may not be generalizable to other populations.

\section{CONCLUSION}

To date, vitamin $\mathrm{D}$ deficiency persists worldwide, and specifically in Saudi Arabia, possibly due to urbanization, demographic shifts, sedentary lifestyle, nutritional deficits, avoidance of sunlight because of the extreme heat, and decreases in the cutaneous production of vitamin D with age. Hypovitaminosis D was related to dyslipidemia and diastolic blood pressure in a group of Saudi postmenopausal women. The precise nature of this association and the optimum levels of vitamin $\mathrm{D}$ for cardiovascular health remain to be elucidated.

\section{ACKNOWLEDGEMENT}

This study was financially supported by a grant number (0334-11) from the KACST. We would like to thank the CEOR, KAU and all the individuals who took part in the study.

\section{REFERENCES}

[1] Bener, Abdulbari, Al-Ali, Mariam and Hoffmann, Georg F. Vitamin $D$ deficiency in healthy children in a sunny country: associated factors. International Journal of Food Sciences and Nutrition 2008; 1-11.

[2] Kanan RM, Al Saleh YM, Fakhoury HM, Adham M, Aljaser S, Tamimi W. Year-round vitamin D deficiency among Saudi female out-patients. Public Health Nutr 2013; 16(3): 544-8. http://dx.doi.org/10.1017/S1368980012002947

[3] Saadi H, Nagelkerke N, Benedict S, et al. Predictors and relationships of serum 25 hydroxyvitamin $D$ concentration with bone turnover markers, bone mineral density, and vitamin D receptor genotype in Emirati women. Bone 2006a; 39: 1136-1143.

http://dx.doi.org/10.1016/j.bone.2006.05.010

[4] Holick MF. Vitamin D deficiency. N Engl J Med 2007; 357: 266-81.

http://dx.doi.org/10.1056/NEJMra070553

[5] Snijder MB, van Dam RM, Visser M, Deeg DJH, Dekker JM, Bouter LM, et al. Adiposity in relation to vitamin $D$ status and parathyroid hormone levels: a population-based study in older men and women. J Clin Endocrinol Metab 2005; 90: 4119-23.

http://dx.doi.org/10.1210/jc.2005-0216

[6] Zittermann A. Vitamin $D$ in preventive medicine: are we ignoring the evidence? Br J Nutr 2003; 89: 552-572. http://dx.doi.org/10.1079/BJN2003837

[7] Chonchol M, Scragg R. 25-Hydroxyvitamin D, insulin resistance, and kidney function in the Third National Health and Nutrition Examination Survey. Kidney Int 2007; 71(2): 134-139. http://dx.doi.org/10.1038/sj.ki.5002002

[8] Martins D, Wolf M, Pan D, et al. Prevalence of cardiovascular risk factors and the serum levels of 25-hydroxyvitamin $D$ in the United States: data from the Third National Health and Nutrition Examination Survey. Arch Intern Med 2007; 167(11): 1159-1165.

http://dx.doi.org/10.1001/archinte.167.11.1159

[9] Zittermann A, Schleithoff SS, Koerfer R. Putting cardiovascular disease and vitamin $D$ insufficiency into perspective. Br J Nutr 2005; 94(4): 483-492. http://dx.doi.org/10.1079/BJN20051544

[10] Ridker PM. High-sensitivity C-reactive protein: potential adjunct for global risk assessment in the primary prevention of cardiovascular disease. Circulation 2001; 103: 1813-1818. http://dx.doi.org/10.1161/01.CIR.103.13.1813

[11] Norman AW. Sunlight, season, skin pigmentation, vitamin D, and 25-hydroxyvitamin D: integral components of the vitamin D endocrine system. Am J Clin Nutr 1998; 67: 1108-10.

[12] Carr $M$. The emergence of the metabolic syndrome with menopause. J Clin Endocrinol Metab 2003; 88: 2404-2411. http://dx.doi.org/10.1210/jc.2003-030242

[13] Rosano GM, Vitale C, Marazzi G, Volterrani M. Menopause and cardiovascular disease: the evidence. Climacteric 2007; 10: $19-24$.

http://dx.doi.org/10.1080/13697130601114917

[14] Norman AW, Bouillon R, Whiting SJ, Vieth R, Lips P. $13^{\text {th }}$ Workshop Consensus for Vitamin D Nutritional Guidelines. J Steroid Biochem Mol Biol 2007; 103(3-5): 204-205. http://dx.doi.org/10.1016/j.jsbmb.2006.12.071 
[15] Lips P. Vitamin D deficiency and secondary hyperparathyroidism in the elderly: consequences for bone loss and fractures and therapeutic implications, Endocr Rev, 2001; 22: 477-501.

http://dx.doi.org/10.1210/edrv.22.4.0437

[16] Soules MR, Sherman S, Parrott E, et al. Executive summary: stages of reproductive aging workshop (STRAW) Park City, Utah, July 2001. Menopause 2001; 8: 402-7. http://dx.doi.org/10.1097/00042192-200111000-00004

[17] World Health Organization. Obesity: Preventing and Managing the Global Epidemic. WHO Technical Report. Series No. 894, WHO, Geneva; 2000.

[18] Valsamakis G, Chetty R, Anwar A, et al. Association of simple anthropometric measures of obesity with visceral fat and the metabolic syndrome in male Caucasian and IndoAsian subjects. Diabet Med 2004; 21: 1339-1345. http://dx.doi.org/10.1111/j.1464-5491.2004.01361.x

[19] World Health Organization. Waist Circumference and WaistHip Ratio. A report of a WHO expert consultation, Geneva, 811 December 2008.

[20] Chobanian AV, Bakris GL, Black HR, et al. The seventh report of the Joint National Committee on Prevention, Detection, Evaluation, and Treatment of High Blood Pressure: The JNC 7 report. JAMA 2003; 289: 2560. http://dx.doi.org/10.1001/jama.289.19.2560

[21] US Department of Health and Human Services. Physical activity and health: a report of the Surgeon General. Atlanta, GA: Centers for Disease Control and Prevention (CDC), National Centers for Chronic Disease Prevention and Health Promotion; 1996.

[22] Cleeman JI, Grundy SM, Becker D, et al. Executive summary of the third report of the National Cholesterol Education Program (NCEP) expert panel on detection, evaluation, and treatment of high blood cholesterol in adults (Adult Treatment Panel III). JAMA 2001; 285: 2486-97. http://dx.doi.org/10.1001/jama.285.19.2486

[23] American Diabetic Association. Diagnosis and Classification of Diabetes Mellitus. Diabetes Care 2005; 28(Suppl 1): S37S52.

http://dx.doi.org/10.2337/diacare.28.suppl 1.S37

[24] Saadi HF, Kazzam E, Ghurbana BA, Nicholls MG. Hypothesis: correction of low vitamin D status among Arab women will prevent heart failure and improve cardiac function in established heart failure. Eur J Hear Fail 2006b; 8: 694-6. http://dx.doi.org/10.1016/j.ejheart.2006.05.006
[25] El-Kaissi S, Sherbeeni S: Vitamin D deficiency in the Middle East and its health consequences for adults from nutrition and health. In: Holick MF, editor. Vitamin D. Springer Science; 2010: 495-503.

http://dx.doi.org/10.1007/978-1-60327-303-9 25

[26] Alissa EM, Bahjri S, Al-ama N, et al. High cardiovascular risk in young Saudi males: Cardiovascular risk factors, diet and inflammatory markers. Clinica Chimica Acta 2006; 365: 288 296.

http://dx.doi.org/10.1016/j.cca.2005.09.007

[27] Alissa EM, Qadi SG, Alhujaili NA, et al. Effect of diet and lifestyle factors on bone health in postmenopausal women. $J$ Bone Miner Metab 2011; 29(6): 725-35. http://dx.doi.org/10.1007/s00774-011-0274-8

[28] Cigolini M, lagulli MP,Miconi V, et al. Serum 25hydroxyvitamin D3 concentrations and prevalence of cardiovascular disease among type 2 diabetic patients. Diabetes Care 2006; 29: 722-4.

http://dx.doi.org/10.2337/diacare.29.03.06.dc05-2148

[29] Wang TJ, Pencina MJ, Booth SL, et al. Vitamin D deficiency and risk of cardiovascular disease. Circulation 2008; 117 503-11.

http://dx.doi.org/10.1161/CIRCULATIONAHA.107.706127

[30] Pittas AG, Harris SS, Stark PC, Dawson-Hughes B. The effects of calcium and vitamin D supplementation on blood glucose and markers of inflammation in nondiabetic adults. Diabetes Care 2007; 30: 980-6. http://dx.doi.org/10.2337/dc06-1994

[31] Tracy RP. Emerging relationships of inflammation, cardiovascular disease and chronic diseases of aging. Int Obes Relat Metab Disord 2003; 27(Suppl 3): S29-S34. http://dx.doi.org/10.1038/sj.ijo.0802497

[32] Vilarrasa N, Vendrell J, Maravall J, et al. Is plasma 25(OH) D related to adipokines, inflammatory cytokines and insulin resistance in both a healthy and morbidly obese population? Endocrine 2010; 38(2): 235-42. http://dx.doi.org/10.1007/s12020-010-9379-4

[33] Schleithoff SS, Zittermann A, Tenderich G, et al. Vitamin D supplementation improves cytokine profiles in patients with congestive heart failure: a double blind, randomized, placebo-controlled trial. Am J Clin Nutr 2006; 83: 754-9.

[34] Braam LA, Hoeks AP, Brouns F, et al. Beneficial effects of vitamin $D$ and $K$ on the elastic properties of the vessel wall in postmenopausal women: a follow-up study. Thromb Haemost 2004; 91: 373-80. 